AL-SYAKHSHIYYAH: Jurnal Hukum Keluarga Islam dan Kemanusiaan Vol. 1; No. 1; P-ISSN: 2685-3248 Juni 2019

\title{
HUKUM MAHAR BERUPA TANAH DALAM KEBIASAAN \\ MASYARAKAT BUGIS BONE MENURUT \\ PERUNDANG-UNDANGAN
}

\author{
Oleh. Hasma \\ Institut Agama Islam Negeri (IAIN) Bone. \\ Email: drahasmamhi@gmail.com
}

\begin{abstract}
Giving Mahar in the tradition of the Bugis Bone community, commonly given by husbands to wives in the form of land. Provision of Mahar in the form of land is regulated in the provisions of the marriage law, UU number 1 of 1974 concerning Marriage, Juncto UUPA number 5 of 1960 concerning Basic Principles of Agrarian Law, Juncto Government Regulation (PP) number 24 of 1997 concerning Land Registration and KHI.

Giving Mahar in the form of land accompanied by a statement that knows and is signed by a local order, namely head of the village related to the location of the Mahar land, is an evidence that is not strong. because proof of ownership is the strongest according to civil law is proof of the authentic deed. Authentic proof of ownership of land must be registered at the Land Agency Office and the certificate of dowry land issued. To provide collateral in the form of legal certainty of dowry ownership in the form of land that should be certified on behalf of the wife.
\end{abstract}

Keywords: Land Certification; Mahar; Legal Development.

\begin{abstract}
Abstrak
Pemberian mahar dalam tradisi masyarakat Bugis Bone, lazim diberikan oleh suami kepada isteri berupa tanah. Pemberian mahar berupa tanah diatur dalam ketentuan hukum perkawinan, yakni Undang-undang No. 1 tahun 1974 tentang Perkawinan juncto Undang-undang No. 5 Tahun 1960 tentang PokokPokok Dasar Agraria (UUPA) jo Peraturan Pemerintah (PP) No. 24 Tahun 1997 Tentang Pendaftaran Tanah serta KHI.

Pemberian mahar berupa tanah yang disertai surat keterangan yang mengetahui dan ditandangani oleh perintah setempat yakni lurah atau kepala desa yang terkait dengan lokasi tanah mahar tersebut, merupakan suatu alat bukti yang tidak kuat, dikarenakan pembuktian kepemilikan yang paling kuat menurut hukum perdata adalah pembuktian akta autentik. Pembuktian kepemilikan yang autentik tentang tanah harus didaftarkan di Kantor Badan Pertanahan serta diterbitkan sertifikat tanah mahar. Untuk memberikan jaminan berupa kepastian hukum kepemilikan mahar berupa tanah seharusya bersertifikat atas nama si isteri.
\end{abstract}

Kata Kunci : Sertifikasi Tanah; Mahar; Perkembangan Hukum. 
AL-SYAKHSHIYYAH: Jurnal Hukum Keluarga Islam dan Kemanusiaan Vol. 1; No. 1; P-ISSN: 2685-3248 Juni 2019

\section{A. Pendahuluan}

Istilah perkawinan dalam Islam disebut dengan nikah yang diderifikasi dari kata nakaha yang berarti melakukan suatu akad atau perjanjian untuk mengikatkan diri antara seorang laki-laki dan perempuan untuk menghalalkan hubungan kelamin antara kedua belah pihak, dengan dasar sukarela dan keridhaan kedua belah pihak untuk mewujudkan suatu kebahagiaan hidup berkeluarga yang diliputi rasa kasih sayang dan ketentraman dengan cara-cara yang diridhoi Allah Swt. ${ }^{1}$

Hak-hak yang harus diterima oleh isteri pada hakikatnya, merupakan salah satu upaya mengangkat harkat dan martabat perempuan, yakni pengakuan terhadap segala sesuatu yang menjadi hak-haknya sebagaimana dalam perkawinan bahwa hak yang pertama ditetapkan oleh Islam adalah hak perempuan menerima mahar. $^{2}$

Mahar termasuk harta yang penting dalam akad nikah. ${ }^{3}$ Mahar merupakan pemberian yang dilakukan oleh pihak mempelai laki-laki kepada pihak mempelai perempuan yang hukumnya wajib. Dengan demikian, istilah shadaqah nihlah, dan mahar merupakan istilah yang terdapat dalam Al-Quran, tetapi istilah mahar lebih dikenal di masyarakat, terutama di Indonesia, sedangkan istilah selain mahar bukan hanya jarang digunakan, melainkan masih banyak orang yang belum memahami maknanya.

Mahar bukanlah pembayaran yang seolah-olah menjadikan perempuan yang hendak dinikahi telah dibeli seperti barang. Pemberian mahar dalam syariat Islam dimaksudkan untuk mengangkat harkat dan derajat kaum perempuan yang sejak zaman jahiliyah telah diinjak-injak harga dirinya. Dengan adanya mahar, status perempuan tidak dianggap sebagai barang yang diperjualbelikan.

Rasulullah Saw. pun pernah mengatakan kepada seseorang yang ingin kawin: "berilah maharnya, sekalipun sebentuk cincin dari besi". Maka yang

\footnotetext{
${ }^{1}$ Lihat Soemiyati, Hukum Perkawinan Islam dan Undang-undang Perkawinan (Cet; IV, Jogyakarta; Liberty, 1999). H.8

${ }^{2}$ Beni Ahmad Saebani, Fikih Munakahat 2 (Cet.VI:Bandung: Pustaka Setia, 2001), h. 12

${ }^{3}$ Abdul Aziz Muhammad Azzamm dan Abdul W ahhab Sayyed Hawwas, Fiqh Munakahat (Cet.I; Jakarta:Imprint Bumi Aksara, 2009), h.174
} 
terpenting ada pemberian kepada isteri dan bukan dilihat dari segi nilainya. Asal kedua belah pihak sudah sama-sama setuju dan rela. Pada umumnya di Indonesia ini yang menjadi mahar adalah seperangkat alat shalat dan al-Qur'an. Di samping itu ada pula perhiasan emas dan benda lainnya berdasarkan kesepakatan calon isteri dan calon suami.

Dalam Kompilasi Hukum Islam Pasal 1 sub (d), bahwa mahar adalah pemberian dari calon mempelai pria kepada calon mempelai wanita, baik berbentuk barang, uang atau jasa yang tidak bertentangan dengan hukum Islam. Pasal $30 \mathrm{KHI}$ menegaskan bahwa calon mempelai pria wajib membayar mahar kepada calon mempelai wanita yang jumlah, bentuk dan jenisnya disepakati oleh kedua belah pihak. Dalam Pasal 33 ayat (1) KHI bahwa penyerahan mahar dilakukan dengan tunai.

Bagi masyarakat Indonesia yang bersifat majemuk dalam adat istiadat, kesukuan dan agama, masing-masing mempunyai pandangan hidup yang berbeda antara yang satu dengan yang lainnya, khususnya dalam hal perkawinan dan kehidupan keluarga. Perkawinan mempunyai pengaruh yang sangat luas baik dalam hubungan kekeluargaan pada khususnya maupun dalam kehidupan bermasyarakat dan bernegara pada umumnya. Karena itu dalam hal ini perlu adanya peraturan hukum yang mengatur mengenai hal-hal yang berkaitan dengan perkawinan.

Dengan demikian perkawinan merupakan akad yang agung dan penting mempunyai pengaruh yang lebih agung, diantaranya hak isteri kepada suami, berupa mahar. Mahar termasuk keutamaan agama Islam dalam melindungi dan memuliakan kaum wanita.

Para ulama fikih sepakat bahwa mahar wajib diberikan oleh suami kepada isterinya baik secara kontan maupun secara tempo, pembayaran mahar harus sesuai dengan perjanjian yang terdapat dalam akad perkawinan. Dalam perkembangan hukum, perceraian terjadi tidak hanya karena kemauan suami, tetapi banyak juga terjadi karena permintaan isteri (cerai gugat). Banyak alasan yang dikemukakan isteri untuk menggugat cerai misalnya, adanya kekerasan dalam rumah tangga, ataupun seringnya terjadi pertengkaran yang pada akhirnya 
AL-SYAKHSHIYYAH: Jurnal Hukum Keluarga Islam dan Kemanusiaan Vol. 1; No. 1; P-ISSN: 2685-3248 Juni 2019

melayangkan gugatan cerai ke pengadilan. Hal ini membuktikan bahwa setiap pasangan tidak selamanya dapat menyelesaikan konflik-konflik yang mereka alami, sehingga menempuh upaya hukum yang ada untuk menyelesaikannya.

Menurut hukum Islam mahar yang telah diberikan kepada isteri adalah menjadi hak milik isteri. Seorang suami tidak boleh menuntut kembali mahar yang telah diberikan apabila isterinya tersebut telah digaulinya, namun pada kenyataannya ada suami yang menuntut kembali pengembalian mahar tersebut karena merasa tidak ada alasan yang kuat bagi isterinya untuk menggugat cerai.

Mahar yang diberikan oleh suami kepada isteri dalam bentuk apapun semata-mata menjadi milik isteri, kecuali isteri bersedia memberikan sebahagian atau seluruhnya dari mahar tersebut kepada suaminya maka pemberian tersebut hanya merupakan sekedar kebaikan hati isteri kepada suaminya.

Indonesia sebagai negara yang berdasarkan hukum positif (Ius Constitutum $)^{4}$ maka seluruh aspek kehidupan masyarakat Indonesia diatur oleh hukum positif yang berdasarkan peraturan perundang-undangan termasuk mengenai perkawinan dan perceraian dan sebagainya. Dengan lahirnya Undangundang No. 1 Tahun 1974 tentang Perkawinan dan Instruksi Presiden No. 1 Tahun 1991 Tentang Kompilasi Hukum Islam (KHI) adalah salah satu bentuk unifikasi dan kodifikasi hukum di Indonesia tentang perkawinan beserta akibat hukumnya.

Mahar dalam KHI, diatur secara terperinci dalam Bab V yang terdiri 9 (Sembilan) Pasal yakni Pasal 30 sampai Pasal 38. Eksistensi mahar dalam hukum keluarga di Indonesia sudah jelas keberadaannya, namun banyak masih kasus sangketa terjadi, maka dari itu untuk menentukan status kepemilikan harta selama perkawinan penting memperoleh kepastian hukum.

Mahar dalam masyarakat Bugis yang lazim diberikan oleh suami kepada isteri adalah tanah, Praktik mahar berupa tanah pada masyarakat Bugis Bone pada kenyataannya masih sering terjadi sengketa, yang kemungkinan dikarenakan tidak efektifnya regulasi perkawinan yang terkait dengan mahar berupa tanah.

${ }^{4}$ Lihat Zainal Asikin. Pengantar Tata Hukum Indonesia (Ed 1; Cet. 3; Jakarta: Rajawali Pers, 2016), h.4 
Jika mengingat asas peraturan perundang-perundangan dalam tata hukum Indonesia misalnya, ada asas peraturan perundang-perundangan "ketentuan hukum yang bersifat khusus menyampingkan ketentuan hukum yang bersifat umum" (lex spesialis derogat lex generalis), bahwa ketentuan hukum tanah di Indonesia sebenarnya telah diatur secara khusus yakni Undang-undang No. 5 Tahun 1960 tentang Pokok- Pokok Dasar Agraria dan Peraturan Pemerintah No. 24 Tahun 1997 Tentang Pendaftaran Tanah. Untuk itu persoalan mahar berupa tanah tidak lepas dari ketentuan hukum ini, begitupun status kepemilikan dan hak milik atau peralihan hak milik, serta pembuktian diatur juga diatur dalam KUHPerdata.

Merujuk pada latar belakang masalah, maka penulis tertarik melakukan penelitian studi perbandingan kekuatan hukum mahar berupa tanah menurut kebiasaan masyarakat Bugis Kabupaten Bone dan perundang-undangan. Dengan meniliti mekanisme dan tata cara pemberian mahar berupa tanah menurut kebiasaan masyarakat bugis Kabupaten Bone dan tata cara pendaftaran tanah menurut kantor pertanahan Kabupaten Bone, serta perbandingan kekuatan hukum menurut kebiasaan masyarakat Bugis Bone dan perundang-undangan tentang mahar berupa tanah.

\section{A. Metodologi Penelitian}

Adapun metodologi penelitian yang peneliti gunakan dalam menjawab permasalahan yaitu:

\section{Jenis Penelitian}

Jenis penelitian ini adalah Field research yaitu suatu jenis penelitian yang digunakan untuk mendapatkan data di lapangan hal ini di Kabupaten Bone, sifat penelitian ini deskriptif kualitatif, yaitu suatu penelitian yang menghasilkan data secara deskriptif. ${ }^{5}$

2. Pendekatan Penelitian

${ }^{5}$ Jalaluddin Rachmat, Metode Penelitian Kualitatif (Cet. I; Jakarta: RajaGrafindo Persada, 2000), h. 1 
AL-SYAKHSHIYYAH: Jurnal Hukum Keluarga Islam dan Kemanusiaan Vol. 1; No. 1; P-ISSN: 2685-3248 Juni 2019

Adapun Pendekatan dalam penelitian ini yaitu; Pendekatan NormatifTeologis; Pendekatan yuridis; Pendekatan sosiologis; Pendekatan antropologi; dan Pendekatan filosofis.

3. Teknik Pengumpulan Data

Mengacu pada kategori penelitian ini sebagai penelitian deskriptif kualitatif, teknik yang digunakan dalam pengumpulan data adalah:

a. Field research, yaitu data-data yang dibutuhkan dan diperoleh dari lapangan dengan menggunakan teknik sebagai berikut:

(1) Observasi. ${ }^{6}$

(2) Wawancara/Interview;

(3) Dokumentasi. ${ }^{7}$

b. Library research, yaitu data-data yang dikumpulkan melalui penulusuran literatur-literatur yang berhubungan dengan masalah yang dibahas dalam penelitian ini.

4. Sumber Data

Oleh karena penelitian ini adalah penelitian Lapangan (Field research) maka dari itu data yang dibutuhkan adalah data Primer dan data skunder sebagai berikut:

a. Data Primer

Data-data yang dibutuhkan dan diperoleh dari lapangan atau lembaga yang terkait dengan penelitian yaitu kantor urusan agama Kabupaten Bone dan Kantor Pertanahan serta masyarakat kabupaten Bone dengan menggunakan teknik sebagai beriku;

(1) Observasi

(2) Wawancara

(3) Dokumentasi

b. Data Sekunder

${ }^{6}$ Lihat Djam'an Satori dan Aan Komariah, Metodologi Penelitian Kualitatif (Cet. I; Bandung Alfabeta, 2009), h. 105.

${ }^{7}$ Lihat Bagong Suyanto dan Sutinah, Metode Penelitian Sosial (Cet, III; Jakarta: Kencana, 2007), h. 69 . 
Data-data yang dibutuhkan dan diperoleh dari penulusuran literatur atau buku-buku serta karya ilmiah regulasi dari lembaga yang terkait dengan penelitian diantaranya yaitu;

(1) Undang-Undang No. 5 Tahun 1960 tentang Pokok- Pokok Dasar Agraria

(2) Instruksi Presiden No. 1 Tahun 1991 tentang Kompilasi Hukum Islam (KHI)

(3) KUHPerdata

(4) Peraturan Pemerintah No. 24 Tahun 1997 Tentang Pendaftaran Tanah.

5. Instrumen Penelitian

Instrument penelitian adalah alat bantu yang digunakan peneliti dalam mengumpulkan data di lapangan. ${ }^{8}$ Adapun instrumen penelitian yang peneliti gunakan adalah:

\section{a. Format Pedoman Observasi}

Pedoman observasi adalah alat pengumpulan data yang digunakan dalam mengamati dan mencatat secara sistematis gejala-gejala yang diteliti, alat yang digunakan berupa daftar jenis kegiatan yang mungkin timbul dan akan diamati oleh peneliti.

b. Format Pedoman Wawancara

Pedoman wawancara adalah alat yang digunakan dalam mengumpulkan data dengan melakukan tanya jawab kepada ahli hukum, tokoh adat tokoh agama atau subjek dan sebagainya atau orang yang dianggap refresentatif untuk mendapatakan informasi-informasi atau keterangan-keterangan yaitu yang berhubungan dengan peneliti.

\section{c. Dokumentasi}

Dokumentasi yaitu suatu proses pengumpulan data yang terkait dengan penelitian yang dilakukan yakni berupa data yang didapatkan dari kantor urusan agama atau kantor pertanahan Kabupaten atau data yang dianggap relavan dengan penelitian ini.

${ }^{8}$ Suharamis Arikunto, Penelitian Suatu Pendekatan Praktek (Cet. XII; Jakarta: Rineka Cipta, 2002), h. 137 
AL-SYAKHSHIYYAH: Jurnal Hukum Keluarga Islam dan Kemanusiaan Vol. 1; No. 1; P-ISSN: 2685-3248 Juni 2019

6. Metode Pengolahan dan Analisis Data;

Dalam mengelola data yang telah dikumpulkan, penulis menggunakan cara berfikir deduktif yakni bertolak dari proposisi umum (premis mayor) yang kebenarannya telah diketahui (premis minor) dan berakhir pada suatu kesimpulan yang bersifat khusus.

Sedangkan analisis data yang digunakan dalam penelitian ini adalah analisis deskriptif kualitatif. Penelaan analisis perbandingan hukum atas kebiaasaan masyarakat Kabupaten Bone dengan peraturan Perundang-undangan mahar berupa tanah.

\section{B. Hasil Penelitian}

\section{Mahar Dalam Perkawinan Masyarakat Bugis Bone}

Berkenaan dengan keyakinan masyarakat bugis bone sejak kerajaan Bone menerima Islam sebagai agama mereka, berkaitan pula dngan masuknya hukum Islam sebagai salah satu aspek panggadereng, sehingga orisinilnya panggadereng tadinya empat aspek, dalam perjalanan sejarahnya akhirnya menjadi lima, yaitu ade`, bicara, rapang, wari dan sara`. Implikasinya adalah bahwa etnik Bugis Bone mengenal dan menerapkan hukum mahar dalam perkawinan mereka. Mahar dalam Islam adalah keharusan berupa pemberian khusus mempelai laki-laki kepada mempelai perempuan. Mahar menjadi dasar halalanya hubungan suami isteri sebuah pasangan, dan mungkin itu juga sebabnya sehingga mahar dalam etnik bugis bone harus disebut dengan terangan dalam ijab qabul (akad nikah).

Dalam perkawinan adat bugis bone pada umunya bahwa mahar disebut juga dengan nama "sompa/ sunreng”. Mattulada menjelaskan, sompa atau sunreng adalah mahar atau maskawin. ${ }^{9}$ Berdasarkan hasil bacaan, sompa/ sunreng dalam perkawinan adat bugis, masyarakat bugis bone merupakan sinkretisme ${ }^{10}$ antara

${ }^{9}$ Mattulada, Latoa Satu lukisan Analitis Terhadap Antropologi Politik Orang Bugis, h.47

${ }^{10}$ Sinkretisme adalah Paduan atau Keterpaduan. Lihat Tim Gama Prees, Kamus Ilmiah Populer: Referensi Ilmiah, Sains Politik, Hukum, EKonomi, Sosial dan Budaya: Edisi Lengkap.(Cet. I: Gama Prees: 2010) h. 581 
adat dengan syariat. Hal ini telah menjadi ciri khas dalam perkawinan pada masyarakat bugis bone yang berlaku sejak dahulu hingga sekarang. ${ }^{11}$

\section{Mahar Berupa Tanah Menurut Masyarakat Bugis Bone}

Kabupaten Bone terdiri dari dua puluh tujuh kecamatan sebagai populasi, serta empat kecamatan yang dijadikan sampel untuk mewakili seluruh kecamatan di Kabupaten Bone.

Berdasarkan data yang diperoleh dari lapangan bahwa pemberian mahar yang diberikan oleh calon suami kepada calon isterinya lazimnya adalah mahar berupa tanah, adapun data dimaksud sebagai berikut;
a. Kecematan Tanete Riattang;
b. Kecematan Tanete Riattang Barat;
c. Kecematan Tanete Riattang Timur;
d. Kecematan Cina.

Tabel. 1

\begin{tabular}{|c|c|c|c|}
\hline Kecamatan & $\begin{array}{c}\text { Jumlah } \\
\text { Perkawinan }\end{array}$ & Periode & Keterangan \\
\hline $\begin{array}{c}\text { Tanete } \\
\text { Riattang }\end{array}$ & 224 & $\begin{array}{l}\text { Januari- } \\
\text { Juni } 2018\end{array}$ & $\begin{array}{l}70 \% \text { mahar berupa tanah sementara } 30 \% \text { adalah mahar } \\
\text { wujud mahar seperti cincin emas kalung emas, pohon } \\
\text { cengkeh, seperangkat alat sholat, dan sebagainya. }{ }^{12}\end{array}$ \\
\hline $\begin{array}{c}\text { Tanete } \\
\text { Riattang } \\
\text { Barat }\end{array}$ & 156 & $\begin{array}{l}\text { Januari- } \\
\text { Juni } 2018\end{array}$ & $\begin{array}{l}70 \% \text { mahar berupa tanah sementara } 30 \% \text { adalah mahar } \\
\text { wujud mahar seperti cincin emas kalung emas, pohon } \\
\text { cengkeh, seperangkat alat sholat, dan sebagainya. }{ }^{13}\end{array}$ \\
\hline $\begin{array}{l}\text { Tanete } \\
\text { Riattang } \\
\text { Timur }\end{array}$ & 203 & $\begin{array}{l}\text { Januari- } \\
\text { Juni } 2018\end{array}$ & $\begin{array}{l}60 \% \text { mahar berupa tanah sementara } 40 \% \text { adalah mahar } \\
\text { wujud mahar seperti cincin emas kalung emas, pohon } \\
\text { cengkeh, seperangkat alat sholat, dan sebagainya. }{ }^{14}\end{array}$ \\
\hline
\end{tabular}

${ }^{11}$ Mattulada, Latoa Satu Lukisan Analitis Terhadap Antropologi Politik Orang Bugis, h. 47

${ }^{12}$ Kantor Urusan Agama (KUA) Kecamatan Tanete Riattang Kabupaten Bone, 20 Juli 2018.

${ }^{13}$ Kantor Urusan Agama (KUA) Kecamatan Tanete Riattang Barat Kabupaten Bone, 30 Juli 2018.

${ }^{14}$ Kantor Urusan Agama (KUA) Kecamatan Tanete Timur Kabupaten Bone, 27 Juli 2018. 
AL-SYAKHSHIYYAH: Jurnal Hukum Keluarga Islam dan Kemanusiaan Vol. 1; No. 1; P-ISSN: 2685-3248 Juni 2019

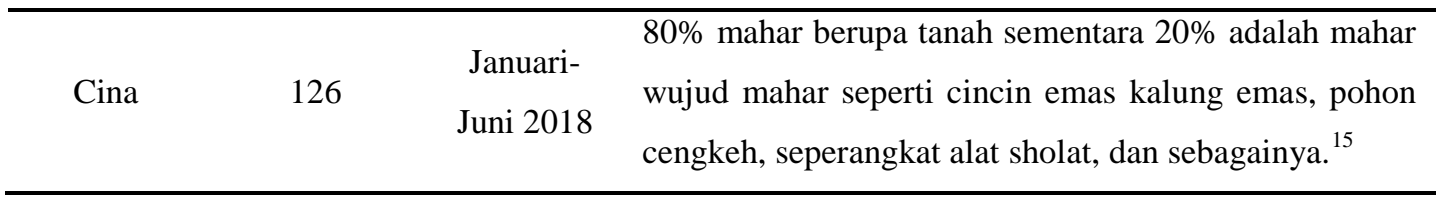

Mekanisme tersebut dari 27 Kantor Urusan Agama (KUA) di Kabupaten Bone telah menjadi kebiasaan dikarenakan belum ada regulasi atau Peraturan Perundang-Undangan yang mengatur secara khusus tentang mahar berupa tanah. ${ }^{16}$

\section{Mekanisme dan tata cara pendaftaran tanah di Kantor Badan Pertanahan Nasional (BPN) Kabupaten Bone}

Ibrahim Nur $^{17}$ menjelaskan behwa Sebagai konsekuensi hukum bahwa tata cara pendaftaran tanah kantor pertanahan di Kabupaten Bone mengacu pada peraturan perundang-undangan.

Berdasarkan data yang diperoleh dari Kantor Badan Pertanahan Kabupaten Bone, bahwa sampai sekarang ini pemberian mahar berupa tanah sebagaimana yang tercantum dalam kutipan akta nikah, belum ada yang melakukan peralihan nama atau menerbitkan sertifikat mahar berupa tanah atas nama si Isteri, padahal berdasarkan PP No. 24 Tahun 1997 bahwa akta nikah dapat dijadikan sebagai alas hak untuk diterbitkan sertifikat tanah mahar.

Perbuatan hukum yang mengakibatkan terjadinya peralihan hak atas tanah dengan melakukan perkawinan dengan pemberian mahar mahar berupa tanah, dalam hal ini obyek tanah yang dialihkan secara keseluruhan atas bidang tanah mahar tersebut dibuktikan dengan sertifikat tanda bukti hak atau biasa disebut sebagai alas hak, misalnya dalam jual beli tanah maka dibuktikan akta jual beli, begitupula dengan pemberian mahar maka alas haknya adalah dapat berupa akta nikah.

\footnotetext{
${ }^{15}$ Kantor Urusan Agama (KUA) Kecamatan Cina Kabupaten Bone, 19 Juli 2018.

16 H. Mappasere, Kepala Kantor Urusan Agama (KUA) Kecamatan Tanete Riattang Kabupaten Bone, Wawancara pada tanggal 20 Juli 2018

${ }^{17}$ Ibrahim Nur, Kepala Seksi Hubungan Hukum Pertanahan Badan Pertanahan Nasional Kabupaten Bone, Wawancara pada tanggal 26 Oktober 2018
} 
Pemberian mahar berupa tanah dalam perkawinan khuusnya masyarakat bugis Bone lazimnya adalah tanah, hal ini berpotensi terjadi sangketa, Olehnya itu menurut Wira Widiastuti ${ }^{18}$ pendaftaran tanah secara normatif berdasarkan Peraturan perundangan yang berlaku yakni Undang-Undang No. 5 Tahun 1960 tentang Peraturan dasar Pokok-Pokok Agraria (UUPA) dan dimplementasikan oleh PP No. 24 Tahun 1997 tentang pendaftaran tanah. sebagai bentuk jaminan kepastian hukum kepada pemilik mahar berupa tanah.

UUPA telah menjamin hak milik atas tanah termasuk tanah mahar kepada perorangan, sebagaima yang dimaksud dalam pasal 19 ayat (1) "Untuk menjamin kepastian hukum oleh pemerintah diadakan pendaftaran tanah diseluruh wilayah Republik Indonesia menurut ketentuan-ketentuan yang diatur dengan peraturan pemerintah" serta diberikan alat bukti yang kuat ketika terjadi sengketa dipengadilan, sebagaimana yang dimaksud dalam Pasal 19 ayat (2) sub. c "pemberian surat-surat tanda bukti hak, yang berlaku sebagai alat pembuktian yang kuat."

Pengertian pendaftaran tanah baru dimulai dalam Pasal 1 angka 1 PP No. 24 tahun 1997 tentang tanah, yaitu serangkaian kegiatan yang dilakukan oleh Pemerintah secara terus-menerus, berkesinambungan dan teratur, meliputi pengumpulan, pengolahan, pembukuan, dan penyajian serta pemeliharaan data fisik dan data yuridis, dalam bentuk peta dan daftar, mengenai bidang-bidang tanah, termasuk pemberian surat tanda bukti haknya bagi bidang-bidang tanah yang sudah ada haknya dan hak milik atas tanah mahar serta hak-hak tertentu yang membebaninya. ${ }^{37}$ hubungan dengan penelitian ini bahwa prinsip pendaftaran hak atas tanah mahar adalah untuk memberikan jaminan keamanan atas pemilikan tanah mahar dan pemindahan haknya, misalnya seorang isteri telah menerima tanah mahar oleh suaminya tidak ada yang dapat mengaggu haknya dari pihak lain termasuk suaminya. ${ }^{19}$

${ }^{18}$ Wira Widiastuti, Kepala Seksi Pengendalian Pertanahan Badan Pertanahan Nasional Kabupaten Bone, Wawancara pada tanggal 19 Oktober 2018

${ }^{19}$ Boedi harsono, Hukum Agraria Indonesia: Sejarah Pembentukan Undang-Undang Pokok Agraria, Isi Dan Pelaksnaannya, (Jilid I; Jakarat : Djambatan, 2003), h 460 
AL-SYAKHSHIYYAH: Jurnal Hukum Keluarga Islam dan Kemanusiaan Vol. 1; No. 1; P-ISSN: 2685-3248 Juni 2019

Mekanisme dan tata cara pendaftaran tanah yang dimaksud dalam Pertuaran ini adalah suatu rangkaian kegiatan yang dilakukan oleh pemerintah untuk mengumpulkan data fisik dan data yuridis dari bidang-bidang tanah yang akan didaftar. Sehingga dikatakan, bahwa pendaftaran tanah mahar merupakan proses administrasi yang merupakan kewenangan dari kantor pertanahan untuk menghasilkan sebuah sertifikat sebagai suatu tanda bukti hak kepemilikan atas sebidang tanah.

\section{Penutup}

\section{Mekanisme dan tata cara Pemberian mahar berupa tanah menurut}

\section{kebiasaan masyarakat Bugis Kabupaten Bone.}

Mekanisme dalam pemberian mahar berupa dalam masyarakat Bugis Kabupaten Bone adalah melampirkan Surat keterangan mahar berupa tanah mengetahui dan ditandangani oleh perintah setempat yakni lurah atau kepala desa yang terkait dengan lokasi mahar tersebut, hal ini belum ada regulasi atau kebijakan yang mengatur secara khusus dari pemerintah. Sehingga hal ini berpotensi terjadi sangketa kemudian hari.

Kebiasaan Pemberian mahar berupa tanah dalam kebiasaan Masyarakat Bugis Bone masih perlu diberikan jaminan hukum berupa regulasi atau kebijakan berdasarkan PP No. 24 Tahun 1997 tentang pendaftaran tanah sehingga meberikan kepastian hukum terhap pemilik tanah mahar

\section{Mekanisme dan tata cara pendaftaran pendaftan mahar berupa tanah di Kantor Badan Pertanahan Nasional (BPN) Kabupaten Bone}

Ibrahim Nur ${ }^{20}$ menjelaskan behwa Sebagai konsekuensi hukum bahwa tata cara pendaftaran tanah kantor pertanahan di Kabupaten Bone mengacu pada peraturan perundang-undangan, pemberian mahar berupa tanah sebagaimana yang tercantum dalam kutipan akta nikah, dapat dijadikan sebagai alas hak untuk diterbitkan sertifikat. Pemberian mahar berupa tanah sebagaimana yang tercantum dalam kutipan akta nikah, dapat dijadikan sebagai alas hak untuk diterbitkan akta

${ }^{20}$ Ibrahim Nur, S.SiT, Kepala Seksi Hubungan Hukum Pertanahan Badan Pertanahan Nasional Kabupaten Bone, Wawancara pada tanggal 26 Oktober 2018 
kepemilikan, sebagai bentuk jaminan hukum untuk memberikan kepastian hukum kepeda pemilik mahar berupa tanah tersebut.

Namun sampai sekarang ini pemberian mahar berupa tanah sebagaimana yang tercantum dalam kutipan akta nikah, belum ada yang melakukan peralihan nama atau menerbitkan sertifikat mahar berupa tanah atas nama si isteri, padahal berdasarkan PP No. 24 Tahun 1997 bahwa akta nikah dapat dijadikan sebagai alas hak untuk diterbitkan sertifikat tanah mahar.

\section{Perbandingan kekuatan hukum menurut kebiasaan Masyarakat Bugis Bone dan Perundang-undangan tentang mahar berupa tanah}

Berdasarkan dalam hierarki peraturan perundang-undangan bahwa peraraturan bersifat khusus mengesampingkan peraturan yang bersifat umum, sementara hukum tanah diatur secara khusus oleh UUPA jo PP No. 24 Tahun 1997 tentang pendaftaran tanah.

Sebagaimana dalam Pasal 19 ayat (2) sub. c UUPA jo Pasal 1 angka 1 PP No. 24 Tahun 1997 tentang pendaftaran tanah, yaitu "serangkaian kegiatan yang dilakukan oleh Pemerintah secara terus-menerus, berkesinambungan dan teratur, meliputi pengumpulan, pengolahan, pembukuan, dan penyajian serta pemeliharaan data fisik dan data yuridis". Kekuatan pembuktian tanah mahar yang tertuang dalam akta nikah masih memerlukan dukungan berupa sertifikat tanah mahar sebagai jaminan untuk memberikan kepastian hukum ketika terjadi sangketa kemudian hari.

Kebiasaan pemberian mahar berupa tanah yang disertai surat keterangan yang mengetahui dan ditandangani oleh perintah setempat yakni lurah atau kepala desa yang terkait dengan lokasi mahar tersebut, merupakan suatu alat bukti yang tidak kuat, dikarenakan pembuktian kepemilikan yang paling kuat menurut hukum perdata adalah pembuktian yang autentik. Berdasarkan UUPA jo PP No. 24 Tahun 1997 tentang pendaftaran Tanah, untuk memberikan jaminan berupa kepastian hukum kepemilikan mahar berupa tanah seharusya bersertifikat atas nama si Isteri. 


\section{Saran}

Berdasarkan kesimpulan di atas, maka selanjutnya penulis mengajukan beberapa saran sebagai berikut:

1. Berdasarkan kebiasaan atau mekanisme dalam pemberian mahar berupa tanah serta melampirkan surat keterangan mahar yang mengetahui dan ditandangani oleh perintah setempat yakni lurah atau kepala desa yang terkait dengan lokasi mahar tersebut, masih perlu ada regulasi khusus dari pemerintah untuk didaftar serta diterbitkan sertifikat tanah mahar.

2. Khususnya dalam pelaksanaan pencatatan perkawinan perlu ada sosialisasi kepada kedua mempelai bahwa mahar berupa tanah diisyaratkan bahwa setelah penerbitan akta nikah harus ditindak lanjuti dan didaftarkan di Badan Pertanahan Nasional untuk diterbitkan sertifikat tanah mahar atas nama si isteri. 


\section{DAFTAR PUSTAKA}

Arikunto, Suharamis. Penelitian Suatu Pendekatan Praktek. Cet. XII; Jakarta: Rineka Cipta, 2002

Asikin, Zainal Pengantar Tata Hukum Indonesia. Ed 1; Cet. 3; Jakarta: Rajawali Pers, 2016

Azzamm, Abdul Aziz Muhammad dan Abdul W ahhab Sayyed Hawwas, Fiqh Munakahat. Cet.I; Jakarta:Imprint Bumi Aksara, 2009

Kantor Badan Pertanahan Nasional (BPN) Kabupaten Bone.

Kantor Urusan Agama (KUA) Kecamatan Cina Kabupaten Bone, 19 Juli 2018

Kantor Urusan Agama (KUA) Kecamatan Tanete Riattang Barat Kabupaten Bone, 30 Juli 2018.

Kantor Urusan Agama (KUA) Kecamatan Tanete Riattang Kabupaten Bone, 20 Juli 2018.

Mattulada, Latoa Satu Lukisan Analitis Terhadap Antropologi Politik Orang Bugis. Cetakan pertama, Makassar: Hasanuddin University Press, 1995

Narbuko, Cholid, dan Abu Ahmadi, Metodologi Penelitian, Cet.II; Jakarta: Bumi Aksara Pustaka, 1997

Rachmat, Jalaluddin, Metode Penelitian Kualitatif, Cet. I; Jakarta: RajaGrafindo Persada, 2000.

Saebani, Beni Ahmad. Fikih Munakahat 2. Cet.VI:Bandung: Pustaka Setia, 2001

Satori, Djam'an dan Aan Komariah, Metodologi Penelitian Kualitatif . Cet. I; Bandung Alfabeta, 2009

Soemiyati, Nn. Hukum Perkawinan Islam dan Undang-undang Perkawinan. Cet; IV, Jogyakarta; Liberty,1999

Suyanto, Bagong dan Sutinah, Metode Penelitian Sosial . Cet, III; Jakarta: Kencana, 2007

Tim Gama Prees, Kamus Ilmiah Populer: Referensi Ilmiah, Sains Politik, Hukum, EKonomi, Sosial dan Budaya: Edisi Lengkap. Cet. I: Gama Prees: 2010 